\title{
8. SEDIMENT PETROLOGY OF THE HYDROTHERMAL MOUNDS ${ }^{1}$
}

\author{
Peter E. Borella, ${ }^{2}$ Deep Sea Drilling Project, Scripps Institution of Oceanography, La Jolla, California \\ and \\ Richard Myers ${ }^{3}$ and Bill Mills, Deep Sea Drilling Project, Scripps Institution of Oceanography, La Jolla, California
}

\begin{abstract}
Sediments in the area of the Galapagos hydrothermal mounds are divided into two major categories. The first group, pelagic sediments, are nannofossil oozes with varying amounts of siliceous microfossils. The second group are hydrothermal sediments consisting of manganese-oxide crust fragments and green nontronitic clay granules. Hydrothermal sediments occur only in the upper half to two-thirds of the cores and are interbedded and mixed with pelagic sediments. Petrologic evidence indicates that hydrothermal nontronite forms as both a primary precipitate and as a replacement mineral of pre-existing pelagic sediment and hydrothermal manganese-oxide crust fragments. In addition, physical evidence supports chemical equations indicating that the pelagic sediments are being dissolved by hydrothermal solutions. The formation of hydrothermal nontronite is not merely confined to the surface of mounds, but also occurs at depth within their immediate area; hydrothermal nontronite is very likely forming today.

Geologically speaking, the mounds and their hydrothermal sediments form almost instantaneously. The Galapagos mounds area is a unique one in the ocean basins, where pelagic sediments can be diagenetically transformed, dissolved, and replaced, possibly within a matter of years.
\end{abstract}

\section{INTRODUCTION}

The Galapagos Spreading Center and hydrothermal mounds area located in the Panama Basin (Fig. 1) has become one of the most densely surveyed and studied areas in the oceans today. First discovered by Klitgord and Mudie in 1972 on a "deep tow" survey, the mounds field occurs 18 to $32 \mathrm{~km}$ south of the Galapagos Rift at $86^{\circ} \mathrm{W}$ longitude, on crust 0.5 to 0.9 million years old (Klitgord and Mudie, 1974). The field extends approximately $27 \mathrm{~km}$ in an east-west direction. Most mounds occur in rows or chains and are parallel, or nearly so, to the axial trend of the Galapagos Rift. However, isolated mounds also exist. Many mounds are located above small vertical displacements in the basement (Lonsdale, 1977). They range in height from less than 1 meter to more than 20 meters, with diameters between 5 and 50 meters. The smaller mounds $(<4 \mathrm{~m})$ have slopes less than $30^{\circ}$, and the higher mounds ( $>4 \mathrm{~m}$ ) have slopes up to vertical (Williams et al., 1979). A shallow moat less than 5 meters deep surrounds many of the mounds (Lonsdale, 1977).

Heat-flow measurements (Sclater and Klitgord, 1973; Williams et al., 1974; Crane and Normark, 1977; and Williams et al., 1979), bathymetric and deep-tow surveys (Klitgord and Mudie, 1974; Lonsdale, 1977), and geochemical studies of the hydrothermal-vent solutions and dredge hauls (Corliss et al., 1978, 1979; Williams et al., 1979; Edmotid et al., 1979) have shown that the mounds field and adjacent regions are areas of intense hydrothermal activity.

\footnotetext{
${ }^{1}$ Honnorez, J., Von Herzen, R. P., et al., Init. Repts. DSDP, 70: Washington (U.S. Govt. Printing Office).

2 Saddleback College, Mission Viejo, California.

3 Present address: Geological Research Division, Scripps Institution of Oceanography.
}

In addition to the DSRV Alvin dives and these surface-sediment and near-surface studies, Leg 54 of the Deep Sea Drilling Project (DSDP) drilled four holes in a mounds field located on crust approximately 0.62 m.y. old. The purpose was to conduct "drilling trials" along the Galapagos Spreading Center and to determine whether a proposed two-leg drilling program in the Galapagos was feasible in light of the difficulties already encountered in drilling young ocean crust with very thin sediment cover in the immediate area. Aside from this, major questions addressed by Leg 54 scientists regarding the mounds were as follows: (1) the origin of the Galapagos mounds and their relationship to hydrothermal circulation patterns in young crust, and (2) the internal stratigraphy and composition of the mounds (Rosendahl, Hekinian, et al., 1980). In addition to the Initial Reports of DSDP Leg 54, Natland et al. (1979), and Schrader et al. (1980) have published articles concerning the mineralogy, stratigraphy, and chemistry of the hydrothermal and pelagic sediments of the Galapagos mounds field.

Utilizing all of this previous work, along with a detailed drilling plan using the newly developed hydraulic piston corer, DSDP Leg 70 drilled four sites (Sites 506509 ) in the Galapagos hydrothermal mounds area (Fig. 1). Our major intent was to address specific questions regarding the origin and spatial relationships of the mounds field and sediments. The sites we drilled ranged from high heat-flow areas (8-23 HFU) with and without mounds to a relatively low heat-flow area (3-5 HFU). (For a detailed analysis and discussion of heat-flow studies, see Sites 506-509 reports and Becker et al., this volume.) In these four localities sediment thickness ranged from 30 to 52 meters. A fifth site (Site 510) was drilled in an area of relatively high heat flow on crust estimated to be $2.7 \mathrm{~m}$.y. old. Sediment thickness here was $115 \mathrm{me}-$ 

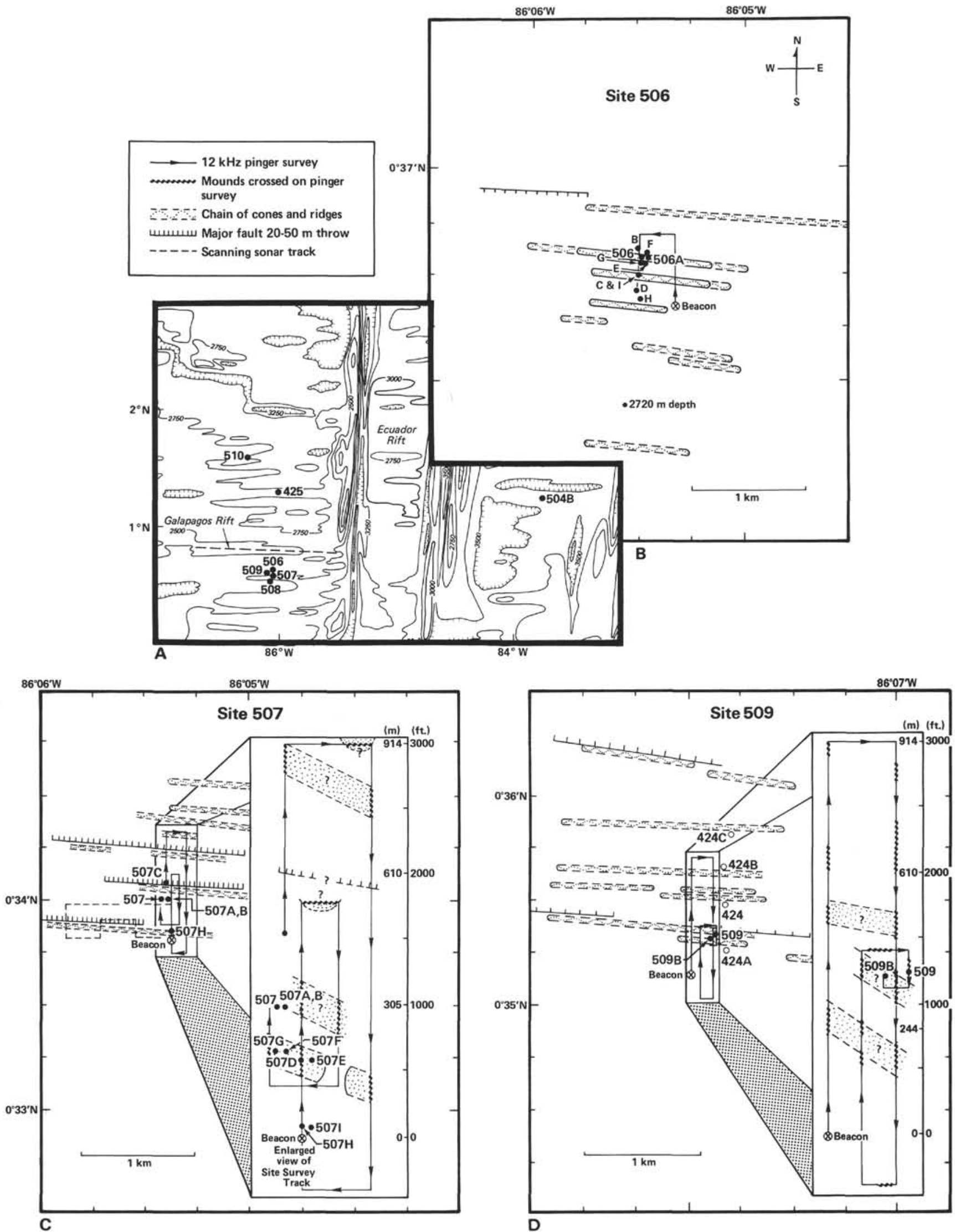

Figure 1. A. General site locality map, DSDP Leg 70. B. Detailed survey, Site 506. C. Detailed survey, Site 507. D. Detailed survey, Site 509. 
ters. Honnorez et al. (1981) discussed the preliminary results of our findings concerning the nature and origin of the hydrothermal mounds.

\section{PURPOSE}

To date, no detailed petrologic or petrographic analysis of hydrothermal-mounds sediments has been performed. Most work has concentrated on bulk chemical, $\mathrm{X}$-ray diffraction, electron microprobe, and electron microscope analyses (e.g., Hoffert et al., 1980; Schrader et al., 1980; Donnelly, 1980; and Dymond et al., 1980, to name a few). The purpose of this chapter is to describe the petrologic and petrographic characteristics of the mounds sediments primarily from hand specimens and thin sections. Scanning transmission electron microscopy (STEM) and elemental analysis, along with Xray diffraction analysis, will be used to support our findings and suppositions. In addition, we hope to present sufficient physical evidence to support or refute existing and proposed models of the origin and distribution of the mounds sediments.

\section{PROCEDURES}

A total of 253 sediment samples were selected for study. The sampling program consisted of taking samples at $10-\mathrm{cm}$ intervals across transitional and stratigraphic boundaries. Each set of samples consisted of two pure end members, hydrothermal sediments and pelagic ooze with transitional and/or mixed samples in between.

From these sets, 125 petrographic thin sections were made. The technique developed to impregnate these sediment samples, especially the expandable hydrothermal clays, though painstaking and unique, proved to be quite successful. For this reason, the procedure is outlined below:

1) Samples are placed in a small aluminum disposable dish and dried in an oven at $72^{\circ} \mathrm{C}$ for $72 \mathrm{hr}$.

2) Samples are impregnated and potted with Petropoxy \#154 and placed in an oven at $105^{\circ} \mathrm{C}$ overnight.

3) The resulting billet is ground flat, first with 120 and then with 400 silicon carbide grit.

4) The flat side of the billet is mounted to a glass slide with Devcon 5 -minute epoxy.

5) The excess sample is trimmed and ground flat using an Ingraham Laboratories' thin-section machine with diamond cup wheel.

6) The sample is polished with 1000 grit.

7) The sample is dried on a hot plate for $1 \mathrm{hr}$.

8) A second glass slide is mounted on the newly polished side of the billet using Petropoxy and placed on a hot plate at $250^{\circ} \mathrm{C}$ for $1 \mathrm{hr}$.

9) The original slide which was held with epoxy (Step 4) is cut off, using the trim-saw side of the thin-section machine.

10) The sample is ground to the desired thickness on the diamond cup wheel.

11) The sample is polished with 1000 grit on a glass plate.

12) Polishing is completed with Linde " $\mathrm{B}$ " $0.05 \mu \mathrm{m}$ Gamma Alumina on a texmet-covered lap wheel.

In addition, we prepared 40 samples of hydrothermal sediments for work with the transmission electron microscope (TEM) with an attached scanning mode (STEM). Two methods of sample preparation were used. The first involved producing a hard block made of casting medium and sediment, which could be cut into $4-\mu$ m-thick slices using a microtome. The procedure used for preparing the samples by this method is as follows:

1) The casting medium used to produce the hard block is called "med-cast." It is highly toxic and should be used under a hood with extreme caution. To prepare the casting medium, follow the manufacturer's instructions.

2) Samples are dried in an oven at $60^{\circ} \mathrm{C}$ for $72 \mathrm{hr}$.

3) They are then dehydrated for $24 \mathrm{hr}$. in $100 \%$ ethyl alcohol.

4) Each sample is dried overnight in an oven at $60^{\circ} \mathrm{C}$.

5) The samples are broken into very small pieces.

6) A small amount of med-cast is injected into the tip of the bulletshaped casting vial, followed by a very small amount of sediment.
7) The remainder of the vial is filled with med-cast.

8) The sample and resin remain at room temperature for $12 \mathrm{hr}$. to allow penetration.

9) The vial is placed in an oven at 60 to $62^{\circ} \mathrm{C}$ for $12 \mathrm{hr}$. to cure the sample.

The second method, which has proved to be less time consuming and just as useful, is very simple.

1) A small amount of sample is placed in distilled water and agitated with an ultrasonic vibrator until most of the grains are in suspension.

2) Prepared, plastic-coated, nonmetal-bearing nylon grids used in TEM work are inserted into the top of the suspension momentarily and then removed.

3) Excess water is drawn off the grit.

4) Grids with the fine-grained sediment are allowed to dry at room temperature.

5) The samples are ready for viewing on the TEM.

\section{RESULTS}

Sediments in the Galapagos hydrothermal mounds area are assigned to two major categories. The first group, pelagic sediments, are essentially nannofossil oozes with varying amounts of siliceous microfossils (diatoms and radiolarians) and foraminifers. The second sediment group includes hydrothermal sediments which are subdivided into manganese-oxide and/or oxyhydroxide-crust fragments and green nontronitic clay granules.

\section{Pelagic Sediments}

Megascopically, the pelagic sediments are very finegrained biogenic oozes. The colors of the oozes vary, with the most dominant colors being a light greenish gray (5GY 8/1), greenish gray (5GY 6/1), and light olive gray $(5 Y 6 / 1)$. However, the mudline in every core is marked by a grayish brown (5YR 3/2) to moderate brown (5YR 3/4) pelagic ooze. The brown color of this uppermost layer is attributed to the presence of $\mathrm{Fe}$ and Mn which have migrated upward through the sediments and become oxidized (Lynn and Bonatti, 1965). The contact between the brown surface ooze and the underlying greenish gray ooze is sharp (Fig. 2). Several other brown "oxidized" layers, interpreted to be "relict" surface layers, are observed at depth within some of the cores (see Borella, this volume).

Most if not all of the pelagic oozes are highly bioturbated, a condition which has obliterated almost all of the internal laminations and bedding. The preservation of biogenic sedimentary structures is excellent. Zoophycus, halo burrows, circular Planolites(?) type, and some open burrows are observed throughout the cores (Fig. 3A). Many burrows crosscut others, indicating more than one episode of burrowing infauna activity. In many of the open burrows and in other mottles dispersed throughout the pelagic oozes are found dark brown to black soupy pyrite and marcassite admixtures. These most likely reflect reducing conditions which exist in these areas.

One 4-cm-thick ash layer was found in Hole 509 at a depth of 12 meters (Fig. 4). This ash is composed almost entirely of acidic glass (i.e., colorless, index of refraction less than 1.54); however, a few large basaltic shards also were present. Except for this layer the only other ash we observed was disseminated throughout the cores in little patches and mottled zones. 


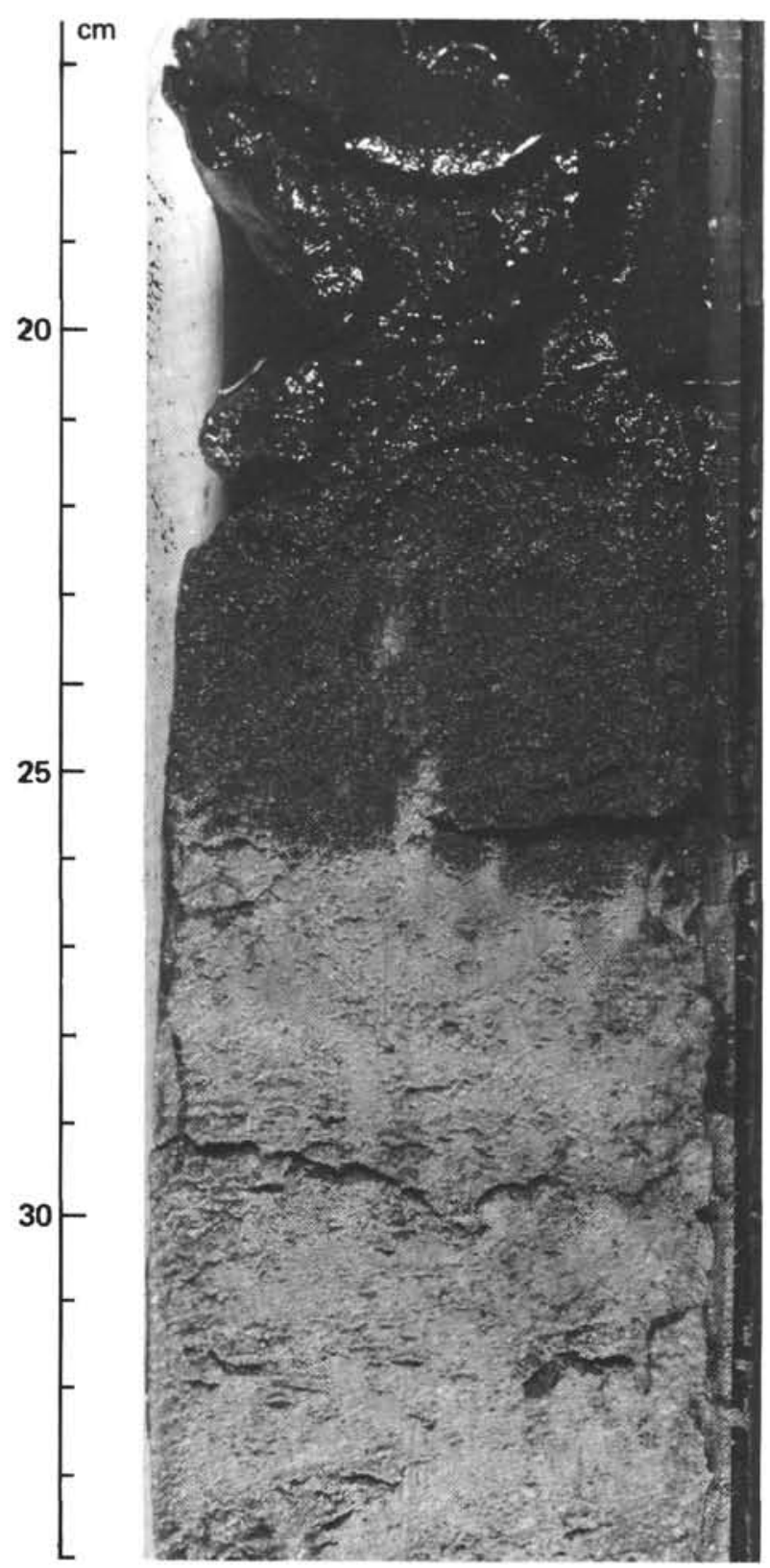

Figure 2. Brown surface "oxidized" layer in sharp contact with underlying greenish gray pelagic ooze. (Sample 506B-1-1, 20-30 cm).

The stratigraphic relationships of the pelagic uozes relative to the hydrothermal sediments is discussed by Borella (this volume). However, for completeness, a summary of the stratigraphies is given in Figure 5.

Microscopically, the pelagic oozes are classified as siliceous foraminifer-nannofossil oozes, foraminifer-nannofossil oozes, and nannofossil oozes. The siliceous components consist of diatoms, radiolarians, and silicoflagellates. Based on smear slides, preservation of microfossils is much better in the off-mounds and nonmounds sites (Sites 508 and 510) than on the mounds. In addition, it was found that the abundance of siliceous microfossils decreases more rapidly with depth on the mounds as compared to the adjacent off-mounds site. For example, in Hole 509B (Fig. 5), the siliceous-microfossil content is greater than $10 \%$ in the pelagic sedi-

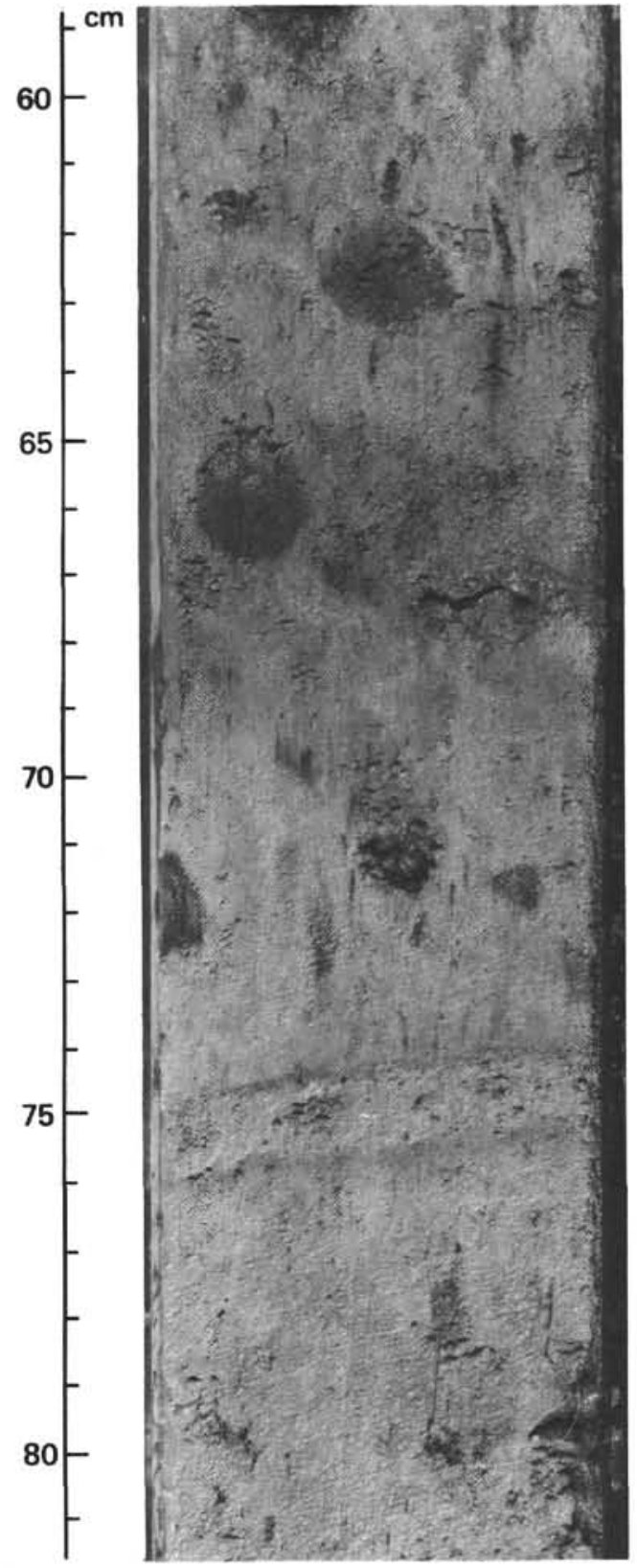

Figure 3. Biogenic sedimentary structures in multicolored pelagic sediment. (Horizontal to subhorizontal Zoophycus at $75 \mathrm{~cm}$; circular Planolites(?)-type burrows at 63 and $67 \mathrm{~cm}$. Gray areas are disseminated ash. Sample 506D-3-2, 60-80 cm.)

ments down to a depth of 7 meters, whereas the adjacent off-mounds Site 509 has siliceous microfossils in abundance $(>10 \%)$ to a depth of 26 meters sub-bottom. This relationship holds true for all mound sites (Fig. 5). The distances between these holes is only tens of meters, and it is very unlikely that the planktonic productivity, CCD, and lysocline depths would vary over such a small area. The hydrothermal activity associated with the formation of the mounds must be responsible for this change in abundance of siliceous microfossils.

Thin sections of the pelagic ooze show that if the sediments were lithified they would be biomicrites (Folk, 1962) or wackestones to mudstones (Dunham, 1962). The 


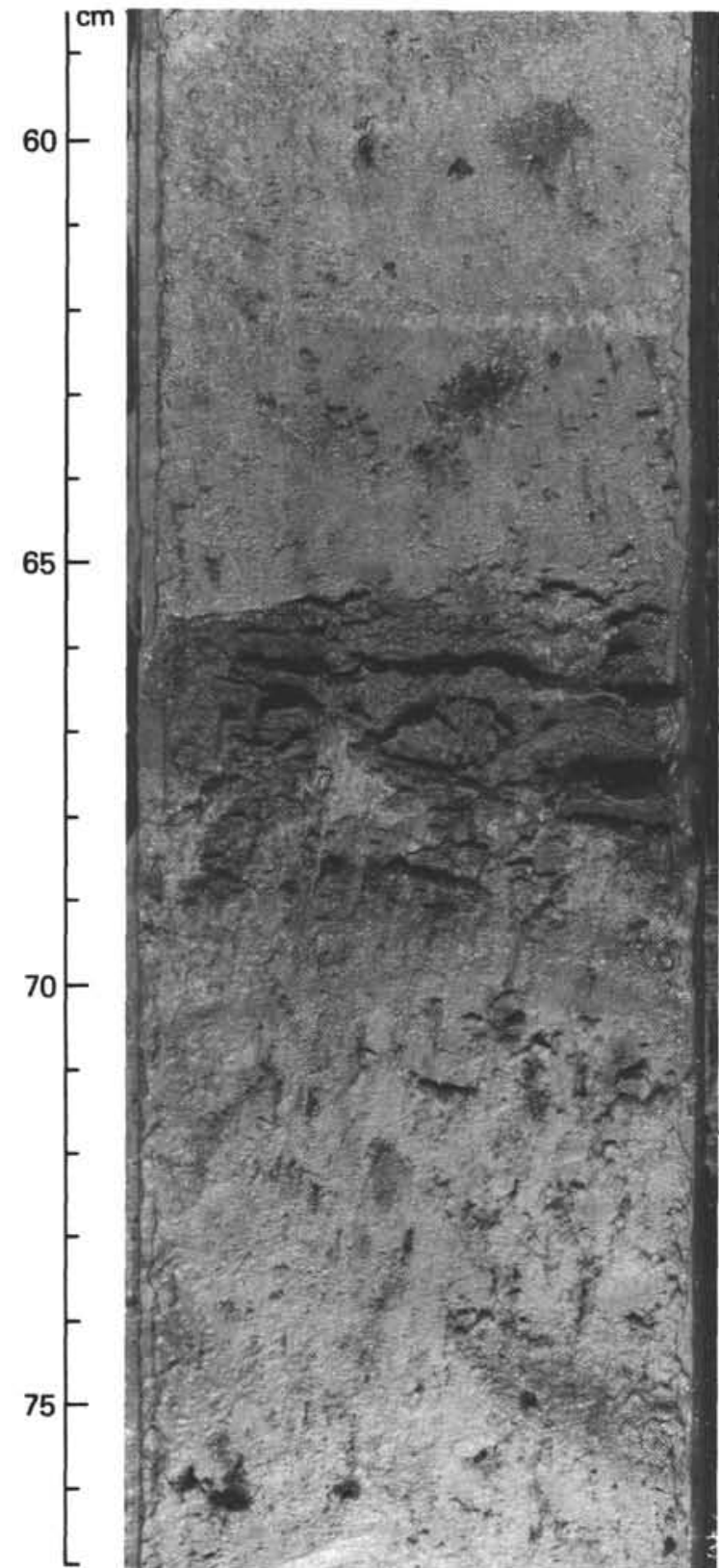

Figure 4. Volcanic ash layer at Site 509 (sub-bottom depth approximately $12 \mathrm{~m}$; Sample 509-4-2, 60-75 cm).

thin sections show that the pelagic oozes are pelletal, further supporting the concept that the sediments have been biologically reworked. Micritic envelopes which enclose many of the fossils suggest additional work by boring algae, bacteria, and/or fungi (Bathurst, 1966; Perkins and Halsey, 1971). Black opaque material commonly in-fills many of the larger fossils and is found scattered throughout some samples appearing as micronodules (see Frontispiece Figs. 4, 5). This black to brown opaque material in the brown surface oxidized zone is the same color in reflected light, with no reflection pleochroism, no anisotropism, and no internal reflection; it probably is amorphous iron and manganese oxide (Lynn and Bonatti, 1965; Moorby and Cronan, this volume). In the remainder of the pelagic oozes, this black material is white to light gray in reflected light with no reflection pleochroism, anisotropism, or internal reflectance, and is probably a manganese oxide or oxyhydroxide (see XRD analysis, Sites 506-510 reports). In some of the thin sections the fossil test has been partially or totally removed or dissolved away, leaving a spherically rounded black opaque internal filling.

The thin sections made from the partially lithified chalk found at Hole 508C are very similar to the siliceous foraminifer-nannofossil oozes. They are pelletal throughout, large foraminifers being the most noticeable microfossil. The fossils are well preserved; some have micritized boundaries. Many of the calcareous fossil grains are partially recrystallized, with the long acicular crystals, possibly aragonite, being transformed into the more blocky and equantly shaped calcite crystals.

\section{Hydrothermal Sediments}

\section{Manganese-Oxide Crusts}

Manganese-oxide crusts and fragments are present in all four holes drilled directly into a mound (Fig. 5). They are associated with and restricted to the hydrothermal mounds area and are not found in off-mounds and nonmounds sites. Vertically within the mounds, the manganese-oxide crust fragments are restricted to within the top few meters, but they never form the uppermost sedimentary layer. However, in two holes (Holes 507D and 509B) manganese-oxide crust fragments are found interspersed within the brown oxidized surface layer. Hole 509B contains the only layer of manganese-crust fragments, which is 1.4 meters thick.

In hand specimens, the manganese-oxide crusts are brownish black and pebble to granule in size (up to $5 \mathrm{~cm}$ long), and they have varying shapes ranging from flat, angular, and saucer-shaped to rounded (Fig. 6). Examination of the textures shows that most of the $\mathrm{MnO}$ fragments are granular but some are botryoidal and smooth on the surface. In cross section, many of the manganese-oxide crusts are laminated or layered with concretionary zones (Frontispiece Fig. 1). Included with the manganese-oxide crust fragments in the brown surface ooze are brownish yellow iron-oxide crust fragments and hollow worm tubes composed of the same iron oxides (Fig. 7). Microscopically, the manganese oxides are white to gray white in reflected light with no reflection pleochroism. Under crossed nichols, the manganese oxides exhibit no anisotropism and no internal reflectance. The X-ray diffraction analyses we performed on board the Glomar Challenger confirmed the presence of todorokite which, along with birnessite, constitutes the major manganese oxides present (Williams et al., 1979). Within one manganese-oxide crust fragment a zonation pattern of brilliant orange and yellow iron oxide or limonite(?) surrounded by black todorokite was present (Frontispiece Fig. 1). Viewed optically in reflected light the limonite or $\mathrm{Fe}$ oxides were gray as compared to a white gray for the manganese oxides. All other characteristics of the two mineral phases under reflected light, both in air and oil, are similar. The lack of identifiable optical properties and poor $\mathrm{X}$-ray diffraction peaks (except for todorokite) suggest 


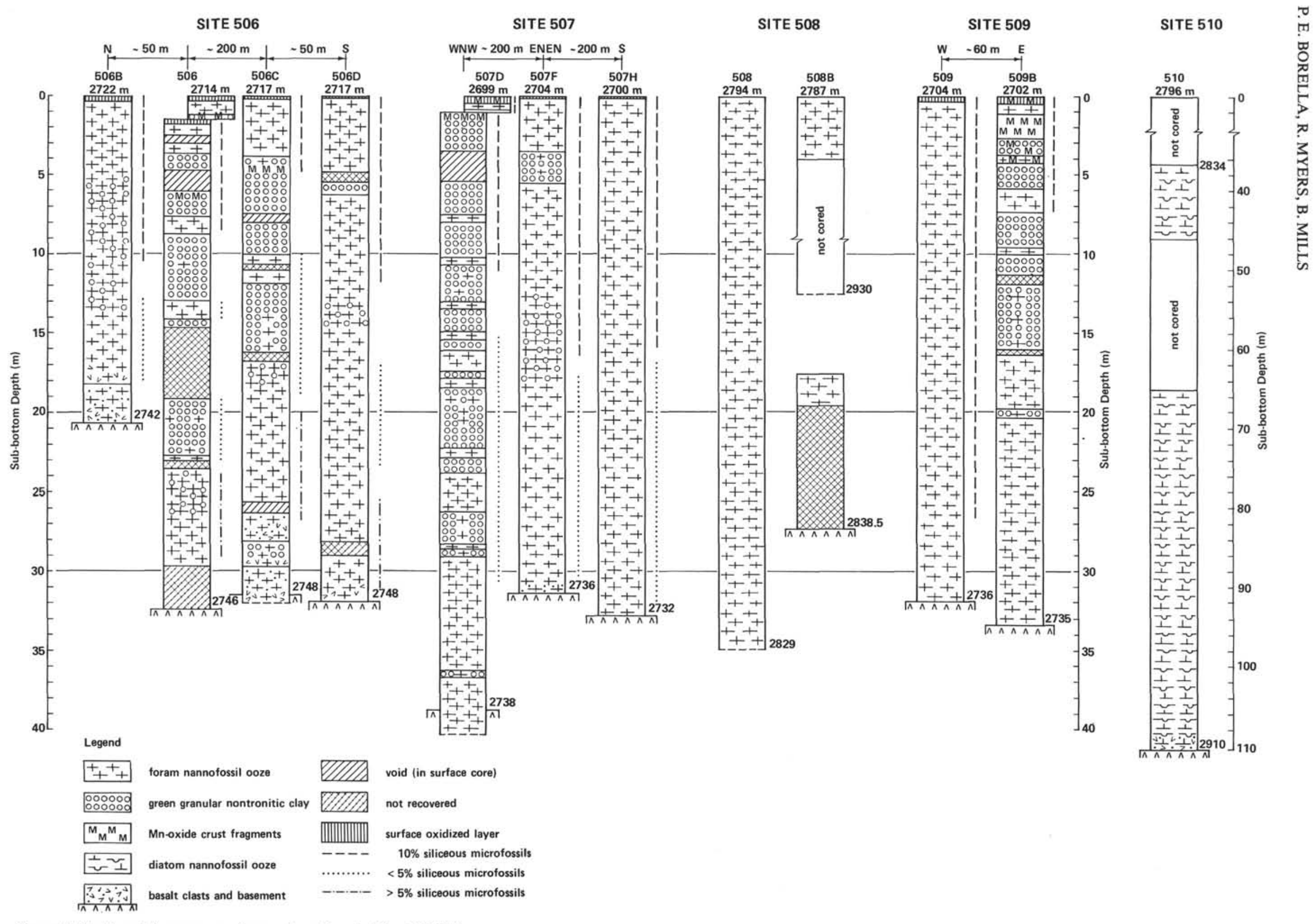

Figure 5. Stratigraphic summary of mounds sediments, Sites 506-510. 


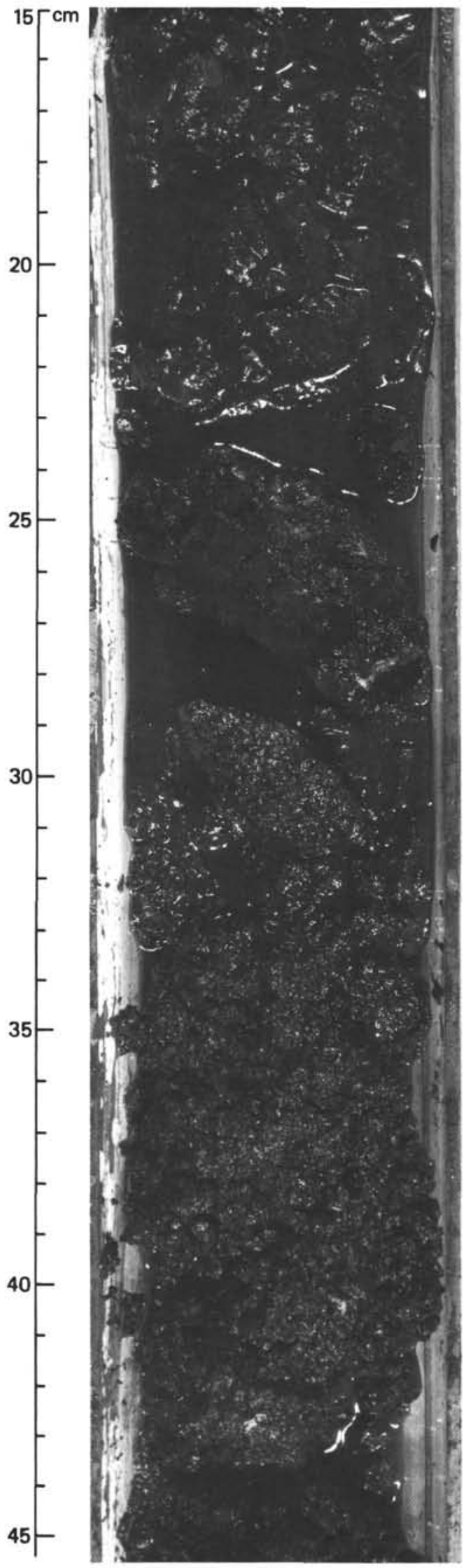

Figure 6. Manganese-oxide crust fragments in direct contact with hydrothermal nontronite. (Contact is at $30 \mathrm{~cm}$; Sample 509B-1-2, $15-45 \mathrm{~cm}$.)

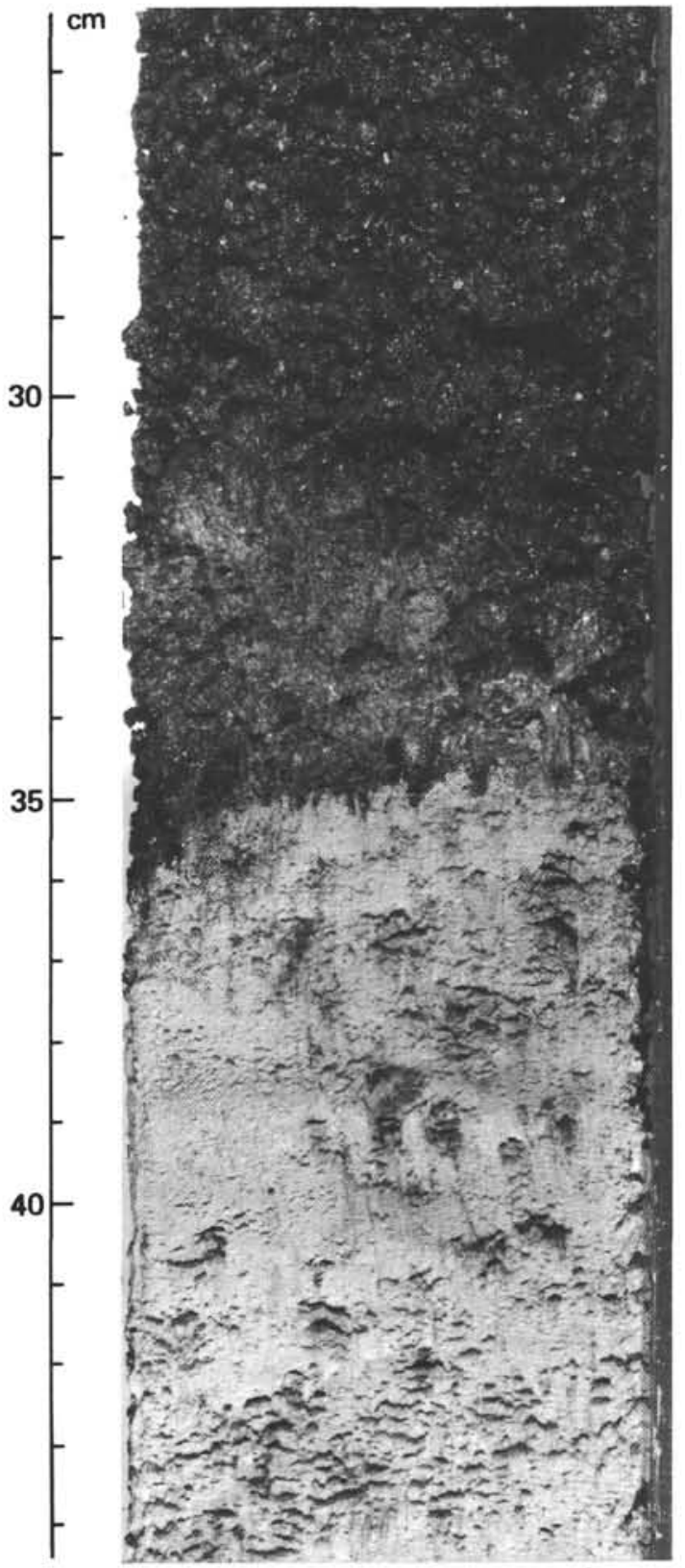

Figure 7. Sharp contact zone between pelagic ooze and hydrothermal nontronite. (Sample 506C-5-1, 30-40 cm.)

that most of the $\mathrm{Fe}$ and $\mathrm{Mn}$ oxides in the crust fragments that we observed are X-ray amorphous (Burns and Burns, 1977).

The element composition of the manganese-oxide crust fragments is apparently quite variable as evidenced by the spectral analysis conducted on the manganese-oxide crust fragments using the transmission electron microscope. For example, based on $\mathrm{K} \alpha$ electron peaks, with intensities plotted relative to silicon, the manganese-oxide crust fragment from Hole 509B (Table 1) has (in addition to $\mathrm{Fe}$ and $\mathrm{Mn}$ ) extremely high amounts of $\mathrm{Cu}$ and $\mathrm{S} . \mathrm{Mg}, \mathrm{Ca}$, and $\mathrm{Ti}$ are less abundant than $\mathrm{Fe}$ and Mn but greater in abundance than $\mathrm{Si}$. Further quantitative analyses of element abundance of the manganese- 
Table 1. Analysis of elements in MnO-crust fragment, Section 509B-1-2. (Note ratios and intensities based relative to silicon.)

\begin{tabular}{|c|c|c|c|c|}
\hline Element & $\begin{array}{l}\text { Intensity } \\
\text { (cps) }\end{array}$ & $\begin{array}{c}\text { Error } \\
(\%)\end{array}$ & $\begin{array}{l}\text { Ratio } \\
\mathrm{I} / \mathrm{I}(\mathrm{Si})\end{array}$ & $\begin{array}{c}\text { Intensity } \\
(\%)\end{array}$ \\
\hline $\mathrm{Mg}$ & 0.1456 & 66.0745 & 2.0396 & 0.7445 \\
\hline $\mathrm{Al}$ & 0.0359 & 338.0120 & 0.5035 & 0.1838 \\
\hline $\mathrm{Si}$ & 0.714 & 209.1156 & 1.0000 & 0.3650 \\
\hline $\mathrm{S}$ & 1.0975 & 20.5719 & 15.3735 & 5.6117 \\
\hline $\mathrm{K}$ & 0.0274 & 580.1706 & 0.3838 & 0.1401 \\
\hline $\mathrm{Ca}$ & 0.1780 & 87.7715 & 2.4939 & 0.9103 \\
\hline $\mathrm{Ti}$ & 0.1104 & 157.1024 & 1.5468 & 0.5646 \\
\hline $\mathrm{Mn}$ & 0.5157 & 27.1747 & 7.2244 & 2.6371 \\
\hline $\mathrm{Fe}$ & 0.3170 & 54.8479 & 4.4405 & 1.6209 \\
\hline $\mathrm{Cu}$ & 19.6712 & 2.3609 & 275.5505 & 100.5821 \\
\hline
\end{tabular}

oxide crusts could provide valuable information concerning economic potential.

\section{Green Nontronitic Clay Granules}

Nontronite has been previously identified as the most abundant smectite mineral present in the hydrothermal sediments (Dymond et al., 1980; Hoffert et al., 1980; Schrader et al., 1980) but an interlayered celadonitenontronite smectite has also been chemically determined (Donnelly, 1980).

Megascopically the nontronite is green to greenish black and forms very friable to semiconsolidated angular grains ranging from less than $1 \mathrm{~mm}$ to greater than $20 \mathrm{~mm}$ in size (Fig. 8A). Occasionally exotic yellow and orange colors are observed, which may indicate that oxidizing conditions exist at depth within the mounds. The grains can easily be crushed between the fingers. The majority of the nontronite is very coarse and granular, but it also appears as a finer-grained, nongranular, and more compact sediment (Fig. 8B). This more compact variety is lighter in color and is usually found in or near gradational contacts separating the granular nontronite from the pelagic oozes. Sometimes, however, the finergrained nontronite is observed sandwiched between coarse granular hydrothermal clay layers.

Contacts between the nontronite and the pelagic oozes are mostly gradational but sharp contacts are also present (Fig. 8). In Hole 509B the lower contact between the MnO-crust layer and nontronite is fairly well defined (Fig. 6), but this may have been produced when the cores were first opened. Usually the manganese-oxide crusts are disseminated in pelagic sediments which directly overlie the smectites. Stratigraphically, layers of nontronite are confined to the upper one-half to twothirds of the cores and are present only on the mounds sites (Fig. 5). In several mounds holes and off-mounds holes, zones of nontronite-rich mottles are present. On the mounds these mottle zones occur just below the last coherent nontronitic layer. In the off-mounds sites, the nontronite-rich mottled zones are not associated with any definite layer within the same core, but stratigraphically they are in a position which can be laterally traced to a hydrothermal layer found in an adjacent mound. (For a complete discussion of the stratigraphy and the mottled zones, see Borella, this volume.) No primary sedimentary structures are present in any of the nontronitic layers. However, beautifully preserved elliptically shaped fecal pellets, up to $2 \mathrm{~mm}$ in diameter, were found in Section 506C-2-2 at $130 \mathrm{~cm}$. The fecal pellets are composed entirely of hydrothermal smectite (see Frontispiece Fig. 14, and XRD analysis, Sites 506-509 reports), which indicates either that some burrowing organism is or was grazing within the hydrothermal smectite or that the original fecal pellets were composed of reworked pelagic sediments and as a result of hydrothermal activity were replaced by nontronite. If the former is the case, then this implies that the hydrothermal nontronite forms at or very near the surface. Burrowing organisms are usually active only down to approximately $50 \mathrm{~cm}$ (Berger et al., 1979). If the latter is the case, then a great deal of pelagic ooze has been replaced by nontronite as a result of hydrothermal activity, and we are looking at ghost fecal pellets. No tracks, trails, or other signs of grazing organisms were observed in the hydrothermal smectites, nor were there burrows crosscutting any boundary between the pelagic and hydrothermal sediments.

Microscopically, the hydrothermal smectites are overwhelmingly green, but yellow, orange, red, and various shades of browns and black are also common (see Frontispiece). The green nontronite is nonpleochroic to very weakly pleochroic, with an index of refraction slightly greater (1.56-1.61) than that of the mounting medium (1.54). In polarized light, the nontronite has a very low birefringence, and detailed optical properties cannot be easily determined. It has been shown that the optical properties of the montmorillonite group are affected by composition, state of hydration, and also by the immersion liquid itself (Deer et al., 1976, p. 239). The nontronite in thin section most commonly appears as finegrained aggregates with lamellar, vermiform, and concentric or spherulitic grain textures (Fig. 9A, and Frontispiece Figs. 11, 12, 16). Well-formed authigenic grains with overgrowths are also observed within the nontronite (Figs. 9B and Frontispiece Fig. 13). Under crossed nichols many of the crystal aggregates have a highly birefringent, yellow to white halo surrounding each grain, which in turn is interlocked into a mosaic (Fig. 9C). Under the TEM at higher magnifications the individual nontronite grains (crystals) are commonly lathlike or appear as thin platelets (Fig. 10), but sometimes they show an interlocking and fibrous form. Spectral analysis confirms that the $\mathrm{Fe}, \mathrm{Mg}$ silicate (nontronite?) is the most common mineral species present (Fig. 11 and Table 2). However varying amounts of $\mathrm{Ti}, \mathrm{K}, \mathrm{S}, \mathrm{Cu}$, and Mn also are present.

All of the above textural observations provide direct evidence to support the hypothesis that the hydrothermal smectite is authigenic in origin and in many instances is a primary and void-filling precipitate. However, to say that the nontronite is only a primary and void-filling precipitate is a half truth. Evidence exists within the thin sections to support the hypothesis that much of the nontronite replaces and/or eventually dissolves the pre-existing pelagic sediments. Microfossils and fecal pellets (allochemical grains) make up 0-20\% 

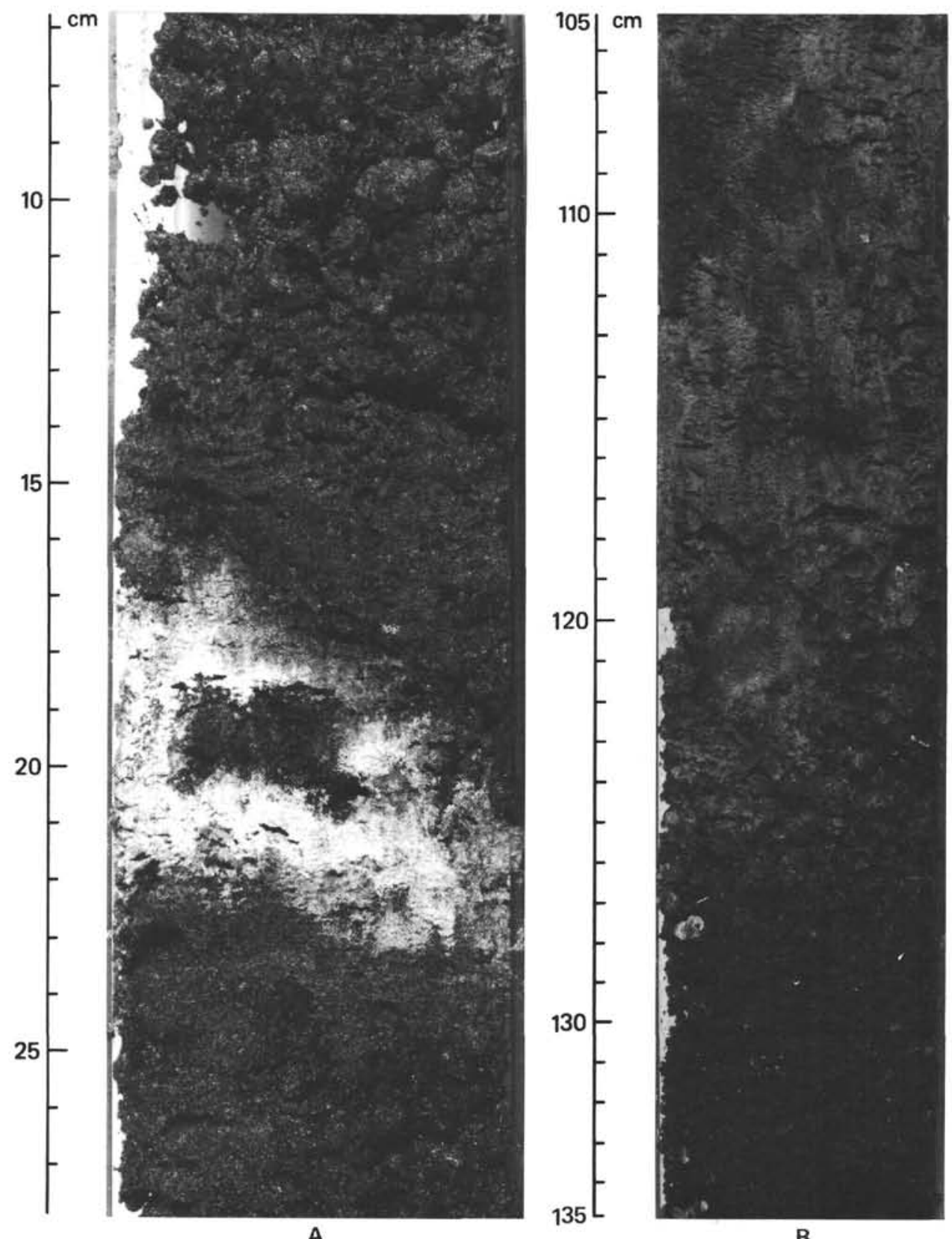

Figure 8. A. Hydrothermal granular nontronite with interlayered pelagic ooze. Note the gradational color change at the borders. (Sample 506-6-2, 10-25 cm.) B. Examples of granular hydrothermal clay $(127-135 \mathrm{~cm})$ overlain by the more compact hydrothermal sediment. Sample 509B-3-2, 105-135 cm.)

of the volume of the thin sections. Numerous examples of partially or wholly replaced calcareous and siliceous microfossils are found (Frontispiece Figs. 6-15). Most of the replaced and partially dissolved fossils occur within the transitional zones located between pelagic and coarse granular hydrothermal sediments. In the middle of the hydrothermal layers, replaced fossils and nontronized ghosts are very sparse. This suggests that the microfossils, which are partially or wholly replaced, will be completely nontronized or dissolved, with no ghost structures being preserved. The presence of partially and completely nontronized fecal pellets in many of the thin sections taken from all depths in the mounds and in nontronitic mottles in the off-mounds sites supports the hypothesis that hydrothermal solutions are replacing pelagic sediments (Frontispiece Figs. 14, 15) or that the organism(s) which produced the fecal pellets grazed in the hydrothermal sediments. Fecal pelletsunlike fossils which are in most cases eventually destroyed-are preserved and are easily identified. Stratigraphic (Borella, this volume), geochemical (Barrett; Moorby and Cronan, this volume), and pore-water chemistry studies (Bender, this volume) indicate that hydrothermal processes are presently active and are occurring within the mounds at depth. Thus, in addition to direct precipitation of nontronite and manganese-oxide miner- 


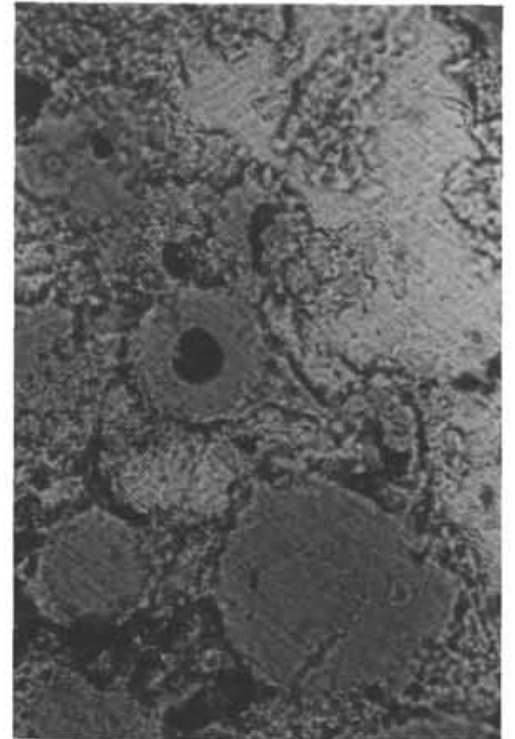

A

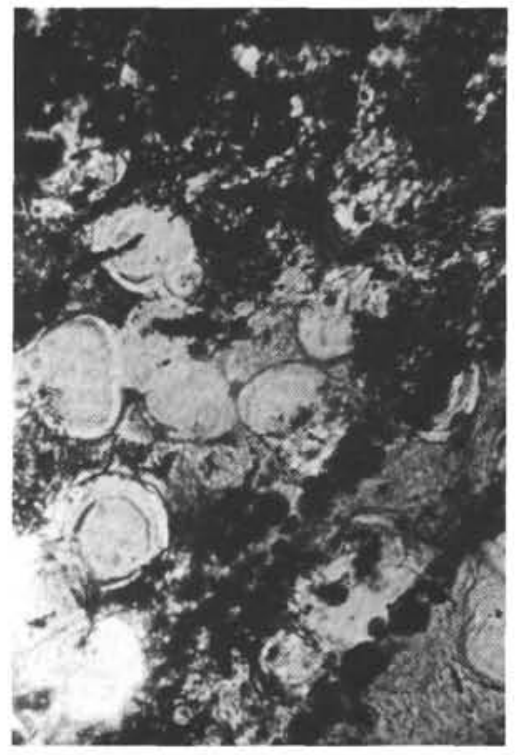

B

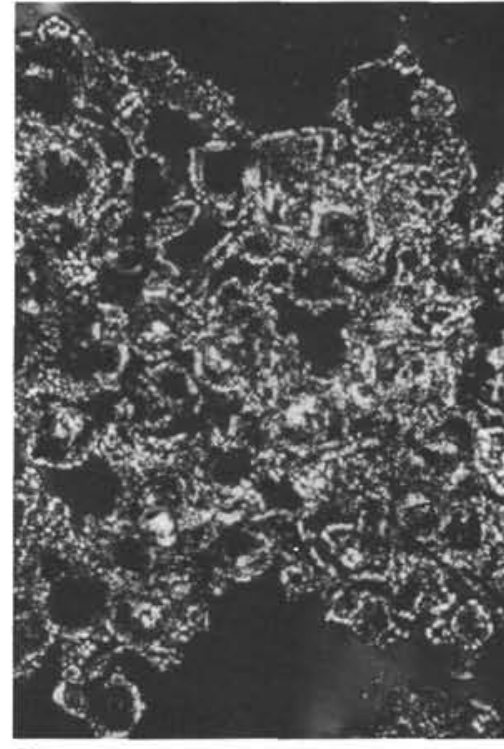

C

Figure 9. A. Sample 509B-3,CC $(4-6 \mathrm{~cm})$. ( $\times 40$, plane light.) Spherulitic grain texture in hydrothermal nontronite. Note dark opaque $\left(\mathrm{MnO}_{2}\right.$ ?) center in one grain and lighter overgrowth zone around edges of grains. B. Sample 509B-3,CC $(4-6 \mathrm{~cm}) .(\times 25$, plane light.) Concentric graingrowth texture in hydrothermal nontronite. C. Sample 509B-1-2, 143-144 cm. $(\times$ Nichols, $\times 125$.) High birefringent halos surrounding hydrothermal grains indicate authigenic grain growth.

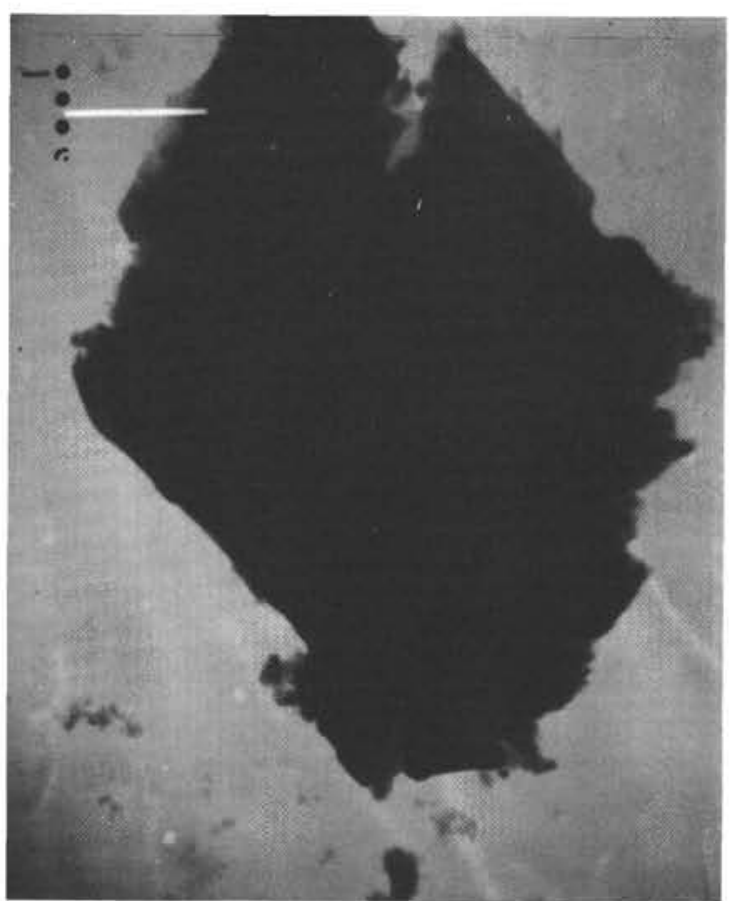

Figure 10. TEM microphotograph of a lathlike nontronite grain (Sample 506-4-2, 86-88 cm).

als at the surface, it seems very likely that the bioturbated and pelleted pelagic sediments have been intruded by hydrothermal solutions and replaced by nontronite.

Black manganese micronodules, clots, clusters, and veinlets are scattered throughout many of the nontronite thin sections (Frontispiece Figs. 2, 3). Optically, this material has the same characteristics as that which comprises the manganese-crust fragments. This manganese material is found at all depths within the cores and in

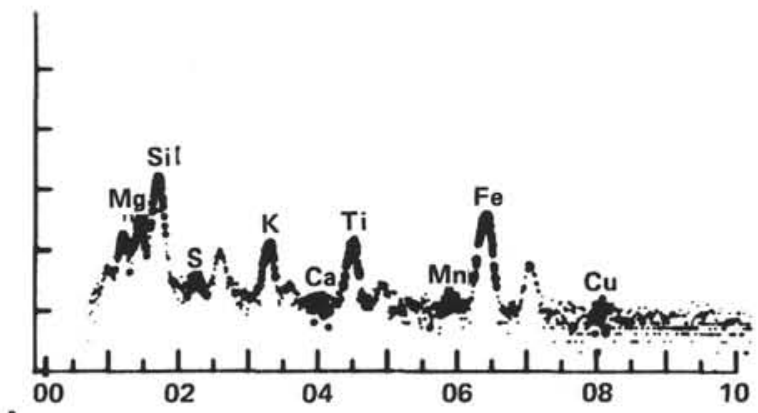

A

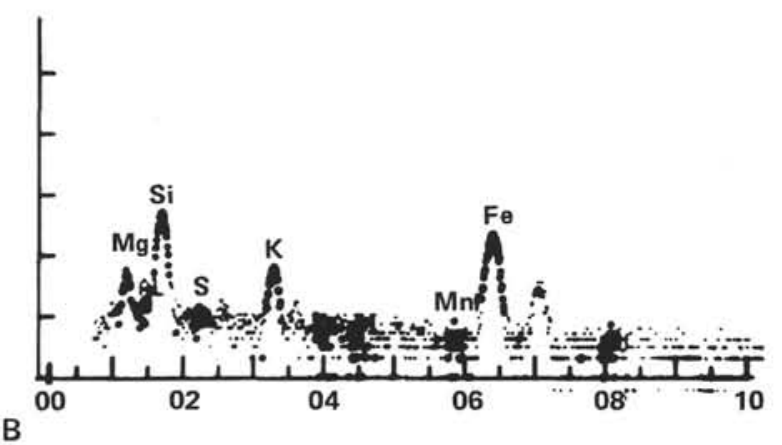

Figure 11. Spectral analysis of green nontronite(?). All elemental ratios and peak intensities are measured relative to silicon. A. Sample $506-4-2,68-88 \mathrm{~cm}$. B. Sample 506-3-2, 138-140 cm.

many cases appears to be replaced partially by nontronite. In many instances the boundaries of the manganeseoxide nodules are vague, with nontronite penetrating into the grain's interior. These nodular growths also sometimes appear as spheres linked by manganese-oxide 
Table 2. Analysis of elements in hydrothermal nontronite fragments. (Note ratios of intensities based relative to silicon.)

\begin{tabular}{|c|c|c|c|c|}
\hline Element & $\begin{array}{l}\text { Intensity } \\
\text { (CPS) }\end{array}$ & $\begin{array}{l}\text { Error } \\
(\%)\end{array}$ & $\begin{array}{l}\text { Ratio } \\
\mathrm{I} / \mathrm{I}(\mathrm{Si})\end{array}$ & $\begin{array}{c}\text { Intensity } \\
(\%)\end{array}$ \\
\hline & \multicolumn{4}{|c|}{ Sample $506-4-2,86-88 \mathrm{~cm}$} \\
\hline $\mathrm{Mg}$ & 12.3233 & 4.1151 & 0.0631 & 3.7631 \\
\hline $\mathrm{Al}$ & 24.9367 & 2.7836 & 0.1277 & 7.6145 \\
\hline $\mathrm{Si}$ & 195.2941 & 0.7647 & 1.0000 & 59.6337 \\
\hline $\mathrm{S}$ & 2.0032 & 14.4826 & 0.0103 & 0.6117 \\
\hline $\mathrm{K}$ & 14.0164 & 3.4293 & 0.0718 & 4.2799 \\
\hline $\mathrm{Ca}$ & 0.0012 & 20503.467 & 0.0000 & 0.0004 \\
\hline $\mathrm{Ti}$ & 16.6440 & 2.9395 & 0.0852 & 5.0823 \\
\hline $\mathrm{Mn}$ & 1.0713 & 20.0830 & 0.0055 & 0.3271 \\
\hline $\mathrm{Fe}$ & 61.1581 & 1.3382 & 0.3122 & 18.6748 \\
\hline \multirow[t]{2}{*}{$\mathrm{Cu}$} & 0.0411 & 464.8861 & 0.0002 & 0.0126 \\
\hline & \multicolumn{4}{|c|}{ Sample 506-3-2, $138-140 \mathrm{~cm}$} \\
\hline $\mathrm{Mg}$ & 3.0900 & 8.1294 & 0.0550 & 3.0979 \\
\hline $\mathrm{Al}$ & 1.1333 & 20.1851 & 0.0202 & 1.1362 \\
\hline $\mathrm{Si}$ & 56.1993 & 1.4282 & 1.0000 & 56.3432 \\
\hline $\mathrm{S}$ & 0.3136 & 56.0263 & 0.0056 & 0.3144 \\
\hline $\mathrm{K}$ & 6.5427 & 4.6453 & 0.1164 & 6.5594 \\
\hline $\mathrm{Ca}$ & 0.3288 & 41.6001 & 0.0059 & 0.3297 \\
\hline $\mathrm{Ti}$ & 0.0862 & 167.1204 & 0.0015 & 0.0864 \\
\hline $\mathrm{Mn}$ & 0.1187 & 99.7070 & 0.0021 & 0.1190 \\
\hline $\mathrm{Fe}$ & 33.8733 & 1.7798 & 0.6027 & 33.9600 \\
\hline $\mathrm{Cu}$ & 0.3254 & 31.2567 & 0.0058 & 0.3262 \\
\hline
\end{tabular}

branches, with the branch appearing more vague than the nodule itself (Frontispiece Fig. 2). An interesting sequence of textural features relating to manganese-oxide material is observed within the pelagic and hydrothermal sediments. Many of the fossils, especially large foraminifers (Orbulina sp.?), are sometimes filled with black opaque Mn-oxide material (Frontispiece Fig. 7). Other times they are in-filled with ordinary pelagic sediments. Within the nontronitic sediments occur perfectly rounded spheres and fecal pellets (Frontispiece Figs. 14, 15 ) which are primarily composed of nontronite, though some have $\mathrm{MnO}$ centers or $\mathrm{MnO}$ material scattered throughout. We suggest that these perfectly spherical grains are replaced fillings from which the outside shell has been removed or replaced and that the nontronite has gradually replaced the Mn oxide and/or pelagic sediment from the outside moving in. The only relict that remains behind is the perfectly spherical shape along with a "doughnut" structure; the center of the doughnut being manganese oxide (Fig. 9A and Frontispiece Fig. 9). Also scattered throughout the nontronite are zones and isolated areas of pelagic sediments and manganese oxide floating in nontronite. These floating relicts provide additional proof that nontronite is replacing or forming at the expense of some of the manganese oxide and pelagic sediments.

The presence of manganese micronodules at depth is interesting in itself. Manganese oxides are apparently formed at the surface and as soon as they are buried they are reduced, with the manganese migrating upward toward the surface. The presence of manganese oxides within the nontronite to depths of at least 24 meters indicates that the manganese oxides are not being entirely reduced. It is quite likely that oxygenated bottom waters are migrating in from the sides of the mounds through the hydrothermal sediments (which are very permeable and porous) or at the boundaries between pelagic and hydrothermal sediments that are directly exposed to bottom waters. Alternatively, oxygen-rich seawater may enter a vent or vents directly where hydrothermal activity has ceased temporarily or completely. Once down the vent(s), the seawater would be able to move laterally through the hydrothermal sediments and prevent or slow down the reduction of the manganese oxides. The presence of oxygen within the pore waters of the hydrothermal sediments most likely explains the wide range in colors found in the mounds hydrothermal smectites and manganese oxides (see Plate 2, "Selected Hydraulic Piston Cores-Leg 70," in the back pocket). The colors simply represent various oxidation stages of the hydrothermal minerals, primarily iron and/or manganese oxides.

\section{DISCUSSION}

While on board the Glomar Challenger we had the opportunity to review certain hypotheses concerning the origin of the hydrothermal sediments and to formulate some additional ideas concerning the origin and distribution of the mounds hydrothermal sediments (Honnorez et al., 1981).

Previous studies on the hydrothermal sediments show that the $\mathrm{Fe}$ in the $\mathrm{Fe}$-oxyhydroxides and nontronites are mainly or completely trivalent, and a simple formula of $\mathrm{Fe}_{4} \mathrm{Si}_{8} \mathrm{O}_{20}(\mathrm{OH})_{4}$ can be used for nontronite. Therefore, essential to the formation of nontronite is the oxidation of ferrous iron $\left(\mathrm{Fe}^{2+}\right)$; three oxidants which are capable of oxidizing $\mathrm{Fe}$ are $\mathrm{O}_{2}, \mathrm{MnO}_{2}$, and $\mathrm{NO}_{3}{ }^{-}$(Honnorez et al., 1981). The reaction for the formation of nontronite is as follows:

$$
4 \mathrm{Fe}^{2+}+8 \mathrm{SiO}_{2}+6 \mathrm{H}_{2} \mathrm{O} \rightarrow \mathrm{Fe}_{4} \mathrm{Si}_{8} \mathrm{O}_{20}(\mathrm{OH})_{4}+8 \mathrm{H}^{+}
$$

The production of eight hydrogen ions in addition to the nontronite is important because these protons can dissolve calcite according to the following equation:

$$
\begin{aligned}
4 \mathrm{Fe}^{2+} & +8 \mathrm{SiO}_{2}+\mathrm{O}_{2}+6 \mathrm{H}_{2} \mathrm{O}+8 \mathrm{CaCO}_{3} \\
& \rightarrow \mathrm{Fe}_{4} \mathrm{Si}_{8} \mathrm{O}_{20}(\mathrm{OH})_{4}+8 \mathrm{Ca}^{2+}+8 \mathrm{HCO}_{3}-
\end{aligned}
$$

A similar reaction for the formation of nontronite using $\mathrm{MnO}_{2}$ as an oxidant is:

$$
\begin{aligned}
4 \mathrm{Fe}^{2+}+8 \mathrm{SiO}_{2} & +2 \mathrm{MnO}_{2}+4 \mathrm{H}_{2} \mathrm{O}+4 \mathrm{CaCO}_{3}-\mathrm{Fe}_{4} \mathrm{Si}_{8} \mathrm{O}_{20}(\mathrm{OH})_{4} \\
& +2 \mathrm{Mn}^{2+}+4 \mathrm{Ca}^{2+}+4 \mathrm{HCO}_{3}^{-}
\end{aligned}
$$

Thus, nontronite forms at the expense of $\mathrm{SiO}_{2}, \mathrm{CaCO}_{3}$, and $\mathrm{MnO}_{2}$-the other major components of the sediments we found in the Galapagos area. If these reactions are indeed occurring in the mounds, then physical evidence should exist to either support or contradict these equations. We know that siliceous-microfossil abundance is drastically reduced within the hydrothermal sediments (see Sites 506-509). The siliceous microfossils that are found in the hydrothermal sediments appear to be replaced and are now composed of nontronite (Frontispiece Fig. 10). Calcareous microfossils are more 
frequently observed in the hydrothermal sediments and show that indeed hydrothermal solutions are dissolving much of the calcium carbonate which composes their tests. We have cited and shown numerous examples of calcareous microfossils that have been partially or almost wholly dissolved and in some instances partially or wholly replaced with hydrothermal nontronite. Ghost fecal pellets are present and found at all depths in the hydrothermal sediments. They are entirely composed of nontronite (see XRD analysis in site reports) and suggest that the originally bioturbated and pelleted pelagic oozes have been replaced by nontronite.

In comparing the thicknesses of the foraminifer-nannofossil ooze on the mounds to those drilled immediately off the mounds, we found that the thicknesses of pelagic ooze that ought to be on the mounds are not. The dissolution of the predominantly calcareous oozes by hydrothermal solutions is the most likely explanation. An alternative is that the pelagic sediments are slumping and sliding off the mounds slopes. We recognized no evidence to support this latter hypothesis although other scientists have (Williams et al., 1979).

Lastly, there is physical evidence to suggest that once manganese oxide has been buried it is also replaced or dissolved away by hydrothermal solutions which deposit nontronite in its place. Geologically speaking, the formation of the hydrothermal sediments and the replacement of the pre-existing pelagic sediment is fast. Each mound site has approximately 10 meters of basal pelagic sediment (see stratigraphic summary) before hydrothermal sediments are found. The age of the crust in the area deduced from spreading rates (Klitgord and Mudie, 1974) ranges from $540-671 \times 10^{3}$ years. Assuming an average thickness of approximately $\mathbf{3 0}$ meters and a uniform sedimentation rate, then it was not until at least $400 \times 10^{3}$ years ago that hydrothermal activity began. However, if we assume that much of the nontronite formed by reacting with and replacing pelagic sediments, then most pelagic sediment was already deposited and the age of the mounds hydrothermal sediments is from the present to a few tens of thousands of years. The correct answer probably lies somewhere in between. The presence of hydrothermal nontronites interbedded with pelagic sediments suggests that hydrothermal activity is episodic, assuming we drilled on a mound crest. The mixed hydrothermal and pelagic sediments with vague and gradational boundaries and nontronitic mottles located in off-mounds sites indicates that hydrothermal solutions are invading, replacing, and dissolving the host sediment. Thus, increased sedimentation of hydrothermal material probably occurs when hydrothermal activity is intense, and very thick, well-defined units or layers result. In periods of quiescence the less violently percolating hydrothermal solutions invade, dissolve, and replace the existing pelagic sediments as evidenced by gradational contacts and highly mixed zones of hydrothermal and pelagic sediments.

\section{SUMMARY}

We have presented petrologic evidence suggesting that hydrothermal nontronite forms both as a primary precipitate and as a replacement mineral of pre-existing pelagic sediment and hydrothermal manganese-oxide crust fragments. During the formation of nontronite by the interaction of hydrothermal solutions with oxygen from bottom waters, Mn-oxide crusts, or $\mathrm{NO}_{3}{ }^{-}$and silica from solutions and sediments, hydrogen ions are liberated, which further react with the pelagic sediments and eventually dissolve or partially dissolve the calcareous components within the biogenic oozes. Numerous examples of replaced, partially replaced, and partially dissolved fossil grains, fecal pellets, and manganeseoxide micronodules and clusters occur, supporting the chemical reactions presented. Thus, dissolution or partial dissolution is the most likely explanation for the lack of pelagic sediments, which ought to be in the mounds but are not. It also may explain the presence of moats (dissolution moats) around many of the mounds (Lonsdale, 1977). The formation of hydrothermal nontronite is not confined just to the surface of the mounds. It also forms at depth within the immediate area of mounds and is very likely forming today. In addition to various petrologic evidence presented, stratigraphic relationships (Borella, this volume), geochemical studies (Moorby and Cronan, this volume; Bender, this volume), and heat-flow measurements (Becker et al., this volume) indicate that the mounds are actively forming today (both on the surface and at depth), with nontronite forming at the expense of some of the pelagic sediments.

The mounds and the hydrothermal sediments within this area form instantaneously, geologically speaking. It is one of the unique areas in the ocean basins where a uniform bed of pelagic sediments can be diagenetically transformed, dissolved, and replaced, possibly within a matter of years.

\section{ACKNOWLEDGMENTS}

We would like to thank our Leg 70 shipboard colleagues for their valuable discussions and opinions concerning the origin of the mounds hydrothermal sediments. Ellen Flentye kindly instructed and assisted us with the scanning transmission electron microscope. Lola Boyce typed the manuscript.

The authors gratefully acknowledge the critical review of this manuscript by Dr. Marian Kastner, Scripps Institution of Oceanography, and Professor Robert H. Osborne, University of Southern California.

The majority of this work was completed while Peter Borella was on sabbatical leave from Riverside City College; salary support during this time is greatly appreciated.

\section{REFERENCES}

Bathurst, R. G. C., 1966. Boring algae, micrite envelopes and lithification of molluscan biosparites. J. Geol., 5:15-31.

Berger, W. H., Ekdale, A. A., and Bryant, P. P., 1979. Selective preservation of burrows in deep sea carbonates. Mar. Geol., 32: 205-230.

Burns, R. G., and Burns, V. M., 1977 Marine Manganese Deposits. In G. P. Glasby (Ed.): New York (Elsevier Publishing Co.), Chapter 7 , pp. $185-248$.

Corliss, J. B., Dymond, J. R., Gordon, L. I., Edmond, J. M., Von Herzen, R. P., Ballard, R. D., Green, K., Williams, D. L., Bainbridge, A., Crane, K., and van Andel, Tj. H., 1979. Submarine thermal springs on the Galapagos Rift. Science, 203:1073-1083.

Corliss, J. B., Lyle, M., Dymond, J. R., and Crane, K., 1978. The chemistry of hydrothermal sediment mound deposits near the Galapagos Rift. Earth Planet. Sci. Lett., 40:12-24.

Crane, K., and Normark, W. R., 1977. Hydrothermal activity and crestal structure of the East Pacific Rise at $21^{\circ} \mathrm{N}$. J. Geophys. Res., 82:5336-5348. 
Deer, W. A., Howie, R. A., and Zussman, J., 1976. Rock Forming Minerals: Sheet Silicates (Vol. 3): New York (Longman Inc.), 226-246.

Donnelly, T. W., 1980. Secondarily modified sediments of the Eastern Pacific: Major-element chemistry of Sites 420, 424, and 425, Deep Sea Drilling Project, Leg 54. In Rosendahl, B. R., Hekinian, R., et al., Init. Repts. DSDP, 54: Washington (U.S. Govt. Printing Office), 329-338.

Dunham, R. J., 1962. Classification of carbonate rocks according to depositional texture. In W. E. Ham (Ed.), Mem. Pet. Geol., 1: 108-121.

Dymond, J., Corliss, J. B., Cobler, P., Muratli, C. M., Chou, C., and Conard, R., 1980. Composition and origin of sediments recovered by deep sea drilling of sediment mounds, Galapagos Spreading Center. In Rosendahl, B. R., Hekinian, R., et al., Init. Repts. DSDP, 54: Washington (U.S. Govt. Printing Office), 377-386.

Edmond, J. M., Measures, C., McDuff, R. E., Chan, L. H., Collier, R., Grant, B., Gordon, L. I., and Corliss, J. B., 1979. Ridge crest hydrothermal activity and the balances of the major and minor elements in the ocean: The Galapagos data. Earth Planet. Sci. Lett., 46:1-18.

Folk, R. L., 1962. Spectral subdivision of limestone types. In W. E. Ham (Ed.), Classification of Carbonate Rocks, a Symposium. Mem. Am. Assoc. Pet. Geol., 1:62-84.

Hoffert, M., Person, A., Courtois, C., Karpoff, A. M., and Trauth, D., 1980. Sedimentology, mineralogy and geochemistry of hydrothermal deposits from Holes 424, 424A, 424B, and 424C (Galapagos Spreading Center). In Rosendahl, B. R., Hekinian, R., et al., Init. Repts. DSDP, 54: Washington (U.S. Govt. Printing Office), 339-376.

Honnorez, J., Von Herzen, R., Barrett, T. J., Becker, K., Bender, M. L., Borella, P. E., Hubberten, H.-W., Jones, S. C., Karato, S., Laverne, C., Levi, S., Migdisov, A., Moorby, S. A., and Schrader, E. L., 1981. Hydrothermal mounds and young ocean crust of the Galapagos: Preliminary Deep Sea Drilling results, Leg 70. Geol. Soc. Am. Bull., Pt. I, 92:457-472.
Klitgord, K. D., and Mudie, J. D., 1974. The Galapagos Spreading Center: A near-bottom geophysical survey. Geophys. J. R. Astron. Soc., 38:563-586.

Lonsdale, P., 1977. Deep-tow observations at the mounds abyssal hydrothermal field, Galapagos Rift. Earth Planet. Sci. Lett., 36: 92-110.

Lynn, D. C. and Bonatti, E., 1965. Mobility of manganese in diagenesis of deep sea sediments. Mar. Geol., 3:457-474.

Natland, J., Rosendahl, B., Hekinian, R., Dmitriev, Y., Fodor, R., Goll, R., Hoffert, M., Humphris, S., Mattey, D., Petersen, N., Roggenthen, W., Schrader, E., Srivastava, R., and Warren, N., 1979. Galapagos hydrothermal mounds: Stratigraphy and chemistry revealed by deep sea drilling. Science, 204:613-616.

Perkins, R. D., and S. D. Halsey, 1971. Geologic significance of microboring fungi and algae in Carolina Shelf sediments. J. Sediment. Petrol., 41:843-853.

Rosendahl, B. R., Hekinian, R., et al., 1980. Init. Repts. DSDP, 54: Washington (U.S. Govt. Printing Office).

Schrader, E. L., Furbish, W. J., Mattey, D., and May, J. A., 1980. Geochemistry and carbonate petrology of selected sediment samples from Deep Sea Drilling Project, Leg 54, East Pacific. In Rosendahl, B. R., Hekinian, R., et al. Init. Repts. DSDP, 54: Washington (U.S. Govt. Printing Office), 319-328.

Schrader, E. L., Rosendahl, B. R., Furbish, W. J., and Mattey, D. P. 1980. Mineralogy and geochemistry of hydrothermal and pelagic sediments from the mounds hydrothermal field, Galapagos Spreading Center, Deep Sea Drilling Project, Leg 54. J. Sediment. Petrol., 50(3):917-928.

Sclater, J. G., and Klitgord, K. D., 1973. A detailed heat flow, topographic and magnetic survey across the Galapagos Spreading Center at $86^{\circ}$ W. J. Geophys. Res., 78:6951-6975.

Williams, D. L., Green, K., van Andel, Tj. H., Von Herzen, R. P. Dymond, J. R., and Crane, K.; 1979. The hydrothermal mounds of the Galapagos Rift: Observations with DSRV Alvin and detailed heat flow studies. J. Geophys. Res., 84(B13):7467-7484.

Williams, D. L., Von Herzen, R. P., Sclater, J. G., and Anderson, R. N., 1974. The Galapagos Spreading Center: Lithospheric cooling and hydrothermal circulation. Geophys. J. R. Astron. Soc., 38: 587-608. 